\title{
Secondary School Students' Awareness of Environmental Education Concepts
}

\author{
Selman ABLAK ${ }^{1}$ \\ Sivas Cumhuriyet University, TURKEY
}

\author{
Erkan YEŞiLTAŞ ${ }^{2}$ \\ Sivas Cumhuriyet University, TURKEY
}

\begin{abstract}
1 Corresponding author: Assist. Prof. Sivas Cumhuriyet University, Department of Social Studies Education, Sivas, Turkey. selmanablak [at] gmail.com. ORCID: 0000-0001-8538-1292

2 Assoc. Prof. Sivas Cumhuriyet University, Department of Social Studies Education, Sivas, Turkey. . erkanyesiltas [at] gmail.com. ORCID: 000-0002-6720-3684
\end{abstract}

\begin{abstract}
Humans have been living in an environment since its existence. Human approaches and attitudes towards the environment in which they live have changed over time. It is hoped the negative attitudes of humans towards nature, the environment and environmental problems will change in a positive way, due to increasing levels of awareness occurring through environmental education. The aim of this study is to measure secondary school students' level of awareness about environmental education concepts. A quantitative survey model is used in this study. The sample of the study was taken at several central secondary schools in the Sivas province for students in Grades $5-8$. There is a total of 524 students in the study. The "Environmental education concepts awareness scale (EECAS)", consists of 22 items and is a data collection tool for this study. The IBM SPSS statistical 23 package program was used to analyze the data. The results were analyzed by means of arithmetic-mean, standard-deviation, Mann-Whitney U test and KruskalWallis test. The data was evaluated with a significance level of 0.05 . As a result of the research, it was concluded that secondary school students who participated in this research had a high level of awareness about the concepts of environmental education overall. On the other hand, it was concluded that there was no significant difference in secondary school students' awareness of environmental education concepts compared to gender and family speech status variables on environmental issues. It was observed that there was a significant difference between variables such as class, mothers' education, fathers' education and family monthly income levels.
\end{abstract}

\section{Keywords}

Environment, Environmental Education, Awareness, Secondary School Students

To cite this article: Ablak, S., Yeşiltaş, E. (2020). Secondary School Students' Awareness of Environmental Education Concepts. Review of International Geographical Education (RIGEO), 10(3), 445-466. Retrieved from http://www.rigeo.org/vol10no3/Number3Summer/RIGEO-V10-N3-9.pdf. . doi: 10.33403/rigeo. 745951 
There is order and balance in everything that exists on earth. In this order and balance, it is impossible not to mention the natural environment. The balance in the natural environment is made possible by the relationship between living things and their physical environment. This is one of the preconditions for achieving natural balance. A small distortion that will occur in any one of these cycles negatively affects the entire system and the balance. However, the increase of human activity on Earth has brought about changes in the balance that exists in the natural environment over time. In fact, since its existence, the environment has offered all its possibilities to people. However, the increase in people's aspirations and expectations in life have also affected their approach towards the environment. In particular, due to developing technology, human beings have started to change the balance in the environment in order to increase their own well-being (Ünal, 2011, p. 68). People who perceive the natural environment as an unlimited resource consume it at random, resulting in the deterioration of the environmental balance (Önder, 2015, p. 116). The Industrial Revolution in the 19th Century was a touchstone in the acceleration of degradation that occurred in this cycle of the natural environment. The disruption in environmental balance, which gained momentum with the Industrial Revolution, gradually increased its impact in the process. As a result of the rapid industrialization experienced in this period, while the welfare level of human beings increased, on the other hand, almost everyone started to be disturbed by the emerging environmental problems (Erten, 2004, p. 1).

Environmental problems that affect humanity, such as factory waste, human waste, harmful gases from factories, exhaust gases, misuse of forested areas, pollution in rivers, unconscious hunting, rapid population growth, uncontrolled urbanization plus many more human factors including global warming, greenhouse effect, nuclear pollution, acid rain, mass extinction of plant and animal species, desertification, ozone depletion and chemical waste off the coast cover the emergence of growing fears about environmental issues (Yücel \& Morgil, 1998, p. 85; Bozkurt \& Cansüngü, 2002, p. 67; Erten, 2003, p. 94-95; Mert, 2006, p. 1). However, people have not realized or wanted to come to the conclusion that the problems mentioned above have, for a long time, been due to human activity. The main environmental problems mentioned above have not only occurred in the region; they have affected the whole world with the effect of the butterfly (Yilmaz, 2019, p. 40). In this sense, environmental problems have become one of the biggest vital problems faced by today's people (Değirmenci, 2013, p. 61). This situation has led to the necessity of addressing the environmental problems that arise due to the protection of the environment with new approaches in national as well as international platforms (Demirbaş \& Pektaş, 2009, p. 196).

In countries that are aware of the destructive impact of humans on the environment, and in turn, also about the destructive impact of such environmental problems on humans, awareness is increasing every day for humans to leave a more livable environment for future generations. In this sense, measures have started to be taken both by the states and through many people, institutions and organizations such as non-governmental organizations, media outlets, universities and educators (Aydın and Ünaldı, 2013, p. 15). Early awareness about environmental problems on a global scale began in the early 1900s in the United States of America with the 
establishment of environmental organizations to help increase levels of environmental awareness from privileged citizens of untouched, uninhabited and beautiful camping and picnic areas, with the hope they can activate their instinct to protect the environment (Callenbach, 2012, p. 29). In Turkey, in the late 1960s, questions about environmental problems began to be openly discussed and discussed in front of the public. The content of the discussions was about nature conservation, raising people's awareness about nature, and providing environmental education. In order to discuss the problems openly in public and to see how big the environmental problems are, many environmentally sensitive people emerged in society and started to organize national and international conferences (Arslan, 2011, p. 248). Within these organizational structures; "Greenpeace", carrying its activities in Turkey for the Turkey Erosion, for Reforestation and the Foundation for the Protection of Natural Habitats (TEMA), Intergovernmental Panel of Climate Change Front, The European Environment Agency, Fauna \& Flora International, The United Nations Environment Program (UNEP), Friends of the Earth, the International Union for conservation of Nature (IUCN) can be shown. At the same time, the aim of environmental education was to eliminate or minimize the impact of these problems in the countries that already had an awareness about this problem; the issue of "environmental education" was raised for this purpose because environmental problems are based on people's lives or value judgments and attitudes are effective. Therefore, an effective understanding of education is important in eliminating the mentioned problems (Gökçe, Kaya, Aktay \& Özden, 2007, p. 454). In other words, it is of great importance, from the early-learning period to give opportunities to increase levels of environmental awareness amongst the new generations who have grown up in terms of the future of humanity (Artvinli \& Demir, 2018, p. 326).

Inclusion of the environment in the education process has become inevitable due to the increase in environmental issues that affect human life in many ways. In this context in the 21st Century, environmental education has become important in many countries. Environmental education is a lifelong process of education, without any interruption, in order to understand, assimilate, defend and apply ecological information of different character and difficulty, as well as to create a sense of environmental responsibility for individuals for the geographical region and country in which they live, and even for the whole world and Planet. While this process is a process of gaining sensitive and positive behavior change, its main purpose is to educate environmental world citizens who are conscious of environmental responsibility, who are conscious of consumption, who see and adopt environmental protection as a philosophy of life, and who feel responsibility for future generations (Atasoy, 2005, p. 112; Kaya, Çobanoğlu \& Artvinli, 2010, p. 412; Demir \& Yalçın, 2014, p. 7).

The main components of environmental education are global warming, greenhouse effect, ecosystem interactions and functioning and food chains. To define these components, global warming is the artificial increase of the temperature of the atmosphere layers close to the earth with the increase of these gases, which are called "greenhouse gases", caused by various activities of humans (Doherty, Claybourne, \& Davidson, 2011, p. 125). The ecosystem is the place where 
a plant or animal lives, that is, its habitat. In a different way, it is the whole that is formed by the mutual relationship and interaction of living things scattered in various habitats on the earth with the inanimate environment in which they reside. (Denhez, 2007, p. 29-30; Doherty, Claybourne \& Davidson, 2011, p. 112-113). The greenhouse effect is that the earth keeps the energy it receives from the Sun just as a greenhouse holds and stores heat and warms the earth (Denhez, 2007, p. 30; Doherty, Claybourne \& Davidson, 2011, p. 102). Finally, the food chain refers to the food and nutrient rings that pass from one organism to another. Animals and plants in an ecosystem with a broad definition depend on each other for food. While one species feed on another, it is actually a food element of another species. This is called the food chain (Kışlalıoğlu \& Berkes, 2001, p. 28-29; Dohety, Claybourne \& Davidson, 2011; Atalay, 2012, p. 401).

Instead of seeing himself as superior to nature or as the master of nature, human should be united with nature, believe that nature has its values, and accept nature as it is, and protect it with love and respect. The behavior and attitudes of people who have assimilated this system of thinking towards nature will be positive as well (Atasoy, 2005, p. 136). These positive behaviors will help the struggles for the protection of the environment and the sustainability of nature. It is only through environmental education that this system of thinking can be made into a way of life by learning and assimilating it. With environmental education, it is aimed to educate environmentally literate individuals who are sensitive to the environment, have gained awareness about environmental problems and can contribute to the solution of these problems (Öztürk \& Zaimoğlu-Öztürk, 2015, p. 117-118; Ministry of Environment and Forestry, 2004, p. 452). For this reason, the importance given to environmental education is increasing every day and more emphasis is placed on it (Ünal, 2011, p. 68-69).

The environmental education activities that started in the children's home and near environment continue with the school age at the pre-school, primary and secondary school years and also, senior-secondary and higher education levels. From this point of view, while individuals have informal contributions to the environmental education processes, this training should also be conducted in formal education institutions. In this sense, environmental education is one of the main tasks of schools (Yangın \& Filik-İsçen, 2013, p. 132) because the process of formal education is more important and valuable for children from which to acquire environmental awareness compared to non-formal education (Erkal, Şafak \& Yertutan, 2011, p. 150). Additionally, children will have acquired an environmental sensitivity and awareness about their responsibility towards the environment, that will continue for a lifetime if they receive environmental education from an early age (Dev-Karakoçan \& Kurtdede-Fidan, 2020, p. 423). At the same time, it is important that this environmental education should be applied on the basis of learning-by-living and learning-by-doing activities provided in appropriate natural environments rather than just being theoretical learning (Demir \& Yalçın, 2014, p. 16). In this respect, the content, scope and quality of the environmental education to be given in formal education are very important (Akınoğlu \& Sarl, 2009, p. 6). Within the framework of this idea, in the process of formal education at secondary school level in Turkey, both directly under the name of environmental education and 
indirectly within different course disciplines, environmental education has started to implicitly occur. While the content for environmental education at secondary school level has been carried out implicitly within the scope of Science and Social Studies courses for many years, there was a decision taken in 2015 to introduce an elective "environmental education" course at secondary school level. The related course was decided by the Board of Education and Training dated 18/07/2016 and numbered 51 to be taught by Science teachers. The necessity of this course in the elective environmental education course curriculum is articulated as "...increasing environmental problems indicate that it would be appropriate to start environmental education at an earlier age. Therefore, the "environmental education course" will serve to increase students' environmental sensitivity and improve their sustainable living skills." (MoNE, 2015, p. 3). However, the Social Studies course plays an active role in environmental education in addition to the subjects or units within the scope of the mentioned elective course and Science course. At this point, in looking at a 2018 Social Studies teaching program, environmental education is within the specific objectives of Social Studies:

"Social Studies curriculum with students' general living environment by recognizing the geographical features of the world with descriptions of the interaction between human and environment and space perception skills'; The aim is to 'recognize the limitations of the natural environment and resources and to try to protect natural resources within environmental sensitivity and to have a sustainable environmental understanding" (MoNE, 2018, p. 5).

On the other hand, the Social Studies course aims to provide students with the opportunity to develop the values of "environmental literacy" skills and "sensitivity to natural environment". Examined current gains in the Social Studies curriculum about the environment, especially environmental problems and environmental concepts related to "people, places and environments in the field of learning" is available. Therefore, in light of this information, formal environmental education should also include the elective course for environmental education together with Science and Social Studies, as part of covering environmental issues, topics and concepts to help secondary school students develop their levels of awareness about the concepts of environmental education.

Environmental education should raise awareness in children and individuals about environmental concepts (Solmaz, 2010, p. 58). Therefore, it is important to learn about environmental concepts in environmental education: "It can be said that students 'awareness and interest in environmental concepts will help them gain positive environmental behaviors" (Ötün, Artun, Temur \& Tozlu, 2017, p. 513). The literature examines the environment, environmental problems, environmental education and environmental education concepts, and contains different studies from primary education to higher education level (Yılmaz, 2002; Çabuk \& Karacaoğlu, 2003; Şama, 2003; Erol, 2005; Özmen, Çetinkaya \& Nehir, 2005; Erol \& Gezer, 2006; Atasay \& Ertürk, 2008; Meydan \& Doğu, 2008; Altunoğlu \& Atav, 2009; Demirbaş \& Pektaş, 2009; Çetin \& Nişancl, 2010; Karatekin, 2011; Aksoy \& Karatekin, 2011; Özgen, 2012; Sungur, 2017; Bozdemir \& Faiz, 2018; Artvinli, Aydın \& Terzi, 2019). In the current research, the students' levels of awareness about the concepts of environmental education, within the scope of environmental education given at secondary school level, are aimed to be determined. Detection of such levels of awareness is important in terms of a developing more livable environment. It 
should not be forgotten that the people who are effective in the formation of environmental problems in the world will be able to reach the awareness of their duty and responsibility in the elimination of these problems through their environmental awareness (Ilgar, 2007, p. 39). Determination of the current situation and deficiencies in environmental education at secondary school level will also contribute to the elimination of possible deficiencies in future learning periods. In a different way, students' levels of awareness about the concepts of environmental education is important in terms of perceiving possible environmental problems and finding alternative solutions. With environmental education, it is aimed to develop an awareness about the environment across all segments of society, to educate individuals who are sensitive to the environment, and to encourage active duty in producing solutions against environmental problems (Ministry of Environment and Forestry, 2004, p. 452). From here we can accept an important step in environmental education at primary and secondary school levels (Karatekin, 2011, p. 35) starts with the determination about the levels of awareness demonstrated by students about the concepts of environmental education which will lead to the possibility of providing a more effective environmental education program.

\section{Purpose of Research}

The aim of this study is to measure the levels of awareness demonstrated by secondary school students about the concepts of environmental education. Within the framework of this basic objective, answers were sought to the following questions: What are the awareness levels of secondary school students towards the concepts of environmental education according to:
a. Gender;
b. Class level;
c. Maternal education status;
d. Paternal education status;
e. Family's monthly income level;

f. Does the family differ according to the state of speaking on environmental issues?

\section{Methodology}

\section{Research Design}

The aim of this study is to measure the levels of awareness of secondary school students about the concepts of environmental education. In other words, the factors affecting the outcome should be determined and the outcome should be evaluated in the best way. If the problem requires the determination of factors that affect an outcome then a quantitative approach is best (Creswell, 2013, p. 20). For this reason, descriptive scanning patterns from quantitative research were used in this study in accordance with its purpose.

The descriptive-scan design provides quantitative or numerical description of trends, attitudes or views through studies on a selected sample (Creswell, 2013, p. 155). Survey with a different expression is research on larger samples of participants' views or characteristics such as interest, skill, attitude, ability, etc., 
related to a subject or event, compared to other studies (Büyüköztürk, Kılıç Çakmak, Akgün, Karadeniz, \& Demirel, 2014).

\section{Data Analysis}

The participant group in the current study is an easily accessible sample of the Grade 5, Grade 6, Grade 7, and Grade 8 students across three state secondary schools in the Sivas city center. The study occurred during the fall semester of the 20192020 academic year. The study constitutes 524 secondary school students across the grade levels. The demographic data for the study group are included in Table 1 , Table 2 and Table 3.

Table 1

Descriptive Statistical Results About Grade Level and Gender Criteria of Participants

\begin{tabular}{llll}
\hline & & F & $\%$ \\
\hline \multirow{4}{*}{ Grade } & 5. Grade & 93 & 17,7 \\
\cline { 2 - 4 } & 6. Grade & 125 & 23,9 \\
\cline { 2 - 4 } & 7. Grade & 158 & 30,2 \\
\cline { 2 - 4 } & 8. Grade & 148 & 28,2 \\
\cline { 2 - 4 } Gender & Total & 524 & 100,0 \\
\hline \multirow{3}{*}{ Female } & 266 & $\% 50,8$ \\
\hline & Male & 258 & 100 \\
\hline
\end{tabular}

\section{Data Collection Tools}

The "Environmental education concepts awareness scale (EECAS)", developed by Ötün, Artun, Temur \& Tozlu (2017) which consists of 22 items, was used in to collect data. A 5s track Likert-scale in the form of "absolutely agree", "agree", "I am ambivalent", "disagree", and "absolutely disagree" were created to reveal student awareness about the concepts of environmental education (global warming, greenhouse effect, food chain, acid rain, ecosystem, etc.). Cronbach's Alpha internal consistency co-efficient of the scale was calculated as 75 in the research conducted by Ötün, Artun, Temur and Tozlu (2017), but the internal consistency co-efficient for the dimensions was not given in the related publication. For the current study, Cronbach's internal consistency co-efficient for the overall Alpha scale was calculated as 87. The internal consistency co-efficient of the dimensions are greenhouse effect size, 78; human effect size, 63; causes of global warming size, 73; environmental pollution dimension, 87; environmental awareness dimension, 81; and importance of Environmental Protection dimension, 76.

\section{Data Analysis}

The SPSS package program was used to analyze the data obtained in the study which seeks to determine the level of awareness about the concepts of environmental education amongst secondary school students. The KolmogorovSmirnov test was performed to determine whether the data met the requirement of conformance to the normal distribution which is one of the parametric test 
conditions. It was observed the data did not show parametric distribution $(\mathrm{p}<, 05)$. Therefore, non-parametric tests were used in the analysis of the data.

Table 2

Normality Test Results for Data

\begin{tabular}{lllll}
\hline $\mathrm{N}$ & $\overline{\mathbf{X}}$ & $\mathrm{Sd}$ & $\mathrm{Z}$ & $\mathrm{p}$ \\
\hline 524 & 3,656 &, 645 & 2,924 &, 000
\end{tabular}

(Flattness: 2,46; Skewness: -1.32)

The results of the study were analyzed by means of arithmetic-mean, standarddeviation, Mann-Whitney U test and Kruskal-Wallis test. The data was evaluated at 0.05 significance level. In order to determine the range of arithmetic averages, 5 columns were moved from 4 December logic. The value of this range is $4 / 5=0.8$. Accordingly:

1.00 to 1.79 I strongly disagree

1.80 to 2.59 disagree

2.60 to 3.39 I'm undecided from

3.40 to 4.19 agree

4.20 and 5.00 Between I absolutely agree with the form can be expressed.

\section{Findings}

The research problem is "What is the level of awareness from secondary school students towards the concepts of environmental education?" The arithmetic-mean of the data has been calculated to find the answer to the question.

When Table 3 is examined, it is seen that the level of awareness about environmental education concepts demonstrated by secondary school students is at the level of "agree" across the scale and in all its lower dimensions. From this point on, it can be said that in general, secondary school students have a high level of awareness about the concepts of environmental education. 
Ablak, S., Yeșiltaș, E. (2020). Secondary School Students' Awareness of Environmental Education...

Table 3

Descriptive Data on Levels of Awareness Levels About Environmental Education Concepts by Secondary School Students

\begin{tabular}{|c|c|c|c|c|}
\hline & & & $\overline{\mathbf{X}}$ & Sd \\
\hline \multirow{5}{*}{ 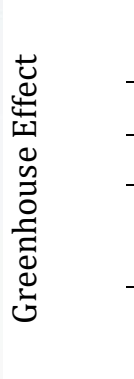 } & $\begin{array}{l}\text { 1. Global warming positively affects the environment we } \\
\text { live in. }\end{array}$ & 524 & 2,028 & 1,392 \\
\hline & 2. Global warming is one of the causes of climate change. & 524 & 4,072 & 1,119 \\
\hline & 3. The melting of glaciers is a result of global warming. & 524 & 4,101 & 1,264 \\
\hline & $\begin{array}{l}\text { 4. Non-renewable energy sources (natural gas, coal, etc.) } \\
\text { it damages our environment. }\end{array}$ & 524 & 3,872 & 1,220 \\
\hline & $\begin{array}{l}\text { 5. Renewable energy sources (wind, geothermal, etc.) } \\
\text { leads to environmental problems. }\end{array}$ & 524 & 2,358 & 1,322 \\
\hline \multirow{3}{*}{ 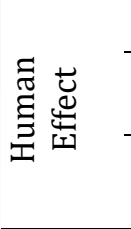 } & 6. Solar is a renewable energy source. & 524 & 3,467 & 1,488 \\
\hline & $\begin{array}{l}\text { 7. The greenhouse effect increases the average } \\
\text { temperature of the Earth. }\end{array}$ & 524 & 3,620 & 1,134 \\
\hline & $\begin{array}{l}\text { 8. Increasing carbon dioxide (CO2) gas increases the } \\
\text { greenhouse effect. }\end{array}$ & 524 & 3,492 & 1,093 \\
\hline \multirow{4}{*}{ 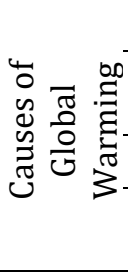 } & 9. Thinning of the ozone layer can cause various cancers. & 524 & 3,536 & 1,162 \\
\hline & $\begin{array}{l}10 \text { The use of fossil fuels should be reduced to prevent } \\
\text { acid rains. }\end{array}$ & 524 & 3,685 & 1,199 \\
\hline & 110ne of the reasons for acid rains is urbanization. & 524 & 3,414 & 1,214 \\
\hline & $\begin{array}{l}12 \text { Damage to natural resources negatively affects the } \\
\text { ecosystem. }\end{array}$ & 524 & 3,990 & 1,180 \\
\hline \multirow{3}{*}{ 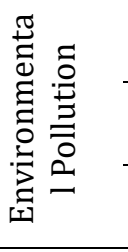 } & $\begin{array}{l}13 \text { Waste such as batteries, plastic glass, paper should be } \\
\text { recycled and reused. }\end{array}$ & 524 & 4,286 & 1,245 \\
\hline & $\begin{array}{l}14 \text { For the protection of the environment, products that } \\
\text { can be recycled should be preferred. }\end{array}$ & 524 & 4,311 & 1,224 \\
\hline & $\begin{array}{l}15 \text { Environmental education is important in protecting } \\
\text { the environment. }\end{array}$ & 524 & 4,137 & 1,186 \\
\hline \multirow{4}{*}{ 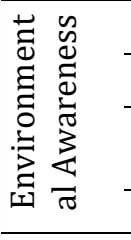 } & 16 Chemical pesticides cause groundwater contamination. & 524 & 3,988 & 1,200 \\
\hline & 17 Erosion damages our environment. & 524 & 3,900 & 1,170 \\
\hline & $\begin{array}{l}18 \text { Population growth is one of the reasons for } \\
\text { environmental pollution. }\end{array}$ & 524 & 3,889 & 1,308 \\
\hline & 19 It can cause environmental pollution in humans. & 524 & 4,169 & 1,205 \\
\hline \multirow{4}{*}{ 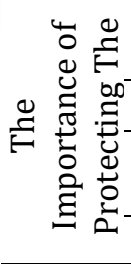 } & $\begin{array}{l}20 \text { Natural disasters (earthquake, flood, etc.) damages the } \\
\text { environment. }\end{array}$ & 524 & 3,938 & 1,241 \\
\hline & 21 The sun is not essential for the food chain. & 524 & 2,211 & 1,312 \\
\hline & $\begin{array}{l}22 \text { Chemical wastes (drugs, industrial waste, etc.) } \\
\text { negatively affects biodiversity. }\end{array}$ & 524 & 3,959 & 1,199 \\
\hline & Total & 524 & & \\
\hline
\end{tabular}

\section{Findings on the Sub-Problem}

There were also sub-problems and sub-questions related to the overall research problem and question: Do the awareness levels of secondary school students about the concepts of environmental education differ according to gender, class level, mother education status, father education status, family monthly income level, family environmental problems? The Mann-Whitney U test and Kruskal-Wallis test were applied for independent groups according to the properties of the arithmetic averaged variables of the data to find answers to the question. 
Table 4

Mann-Whitney U Test Results on Levels of Awareness About Environmental Education Concepts by Secondary School Students According to The Variable of Gender

\begin{tabular}{lllllll}
\hline Gender & $\mathrm{N}$ & Mean Rank & $\begin{array}{l}\text { Ordinal } \\
\text { Sum }\end{array}$ & $\mathrm{U}$ & $\mathrm{Z}$ & $\mathrm{P}$ \\
\hline Male & 266 & 265,70 & 70677,50 & $-33461,50$ &,- 492 &, $623^{*}$ \\
\hline Female & 258 & 259,20 & 66872,50 & 330 & \\
\hline
\end{tabular}

$(* \mathrm{*}>0,05)$

In Table 4, the Mann-Whitney U test examined whether levels of awareness about concepts of environmental education by secondary school students differed by gender. The analysis showed that the awareness levels from secondary school students about environmental education concepts did not show any significant difference compared to the gender variable $(U=33461,50, p>0,05)$.

Table 5

Kruskal-Wallis Test Results for The Levels of Awareness About Environmental Education Concepts by Secondary School Students According to The Variable of Grade Level

\begin{tabular}{|c|c|c|c|c|c|c|c|}
\hline $\begin{array}{l}\text { Dimensi } \\
\text { on }\end{array}$ & Grade & $\mathrm{N}$ & MR & Sd & $\chi^{2}$ & $\mathrm{p}$ & $\begin{array}{l}\text { Significant } \\
\text { Differences }\end{array}$ \\
\hline \multirow{4}{*}{ 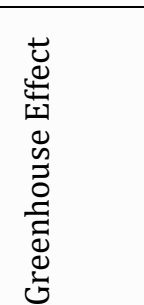 } & 5.grade(a) & 93 & 279,53 & \multirow{4}{*}{3} & \multirow{4}{*}{2,315} & \multirow{4}{*}{,510 } & \multirow{4}{*}{ (21) } \\
\hline & 6.grade (b) & 125 & 268,85 & & & & \\
\hline & 7.grade(c) & 158 & 256,79 & & & & \\
\hline & 8.grade (d) & 148 & 252,53 & & & & \\
\hline \multirow{4}{*}{ 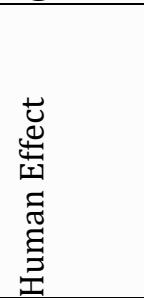 } & 5.grade(a) & 93 & 174,44 & \multirow{4}{*}{3} & \multirow{4}{*}{51,879} & \multirow{4}{*}{, $000^{*}$} & \multirow{4}{*}{$\begin{array}{l}a-b \\
a-c \\
a-d \\
b-d \\
c-d\end{array}$} \\
\hline & 6.grade(b) & 125 & 248,65 & & & & \\
\hline & 7.grade(c) & 158 & 276,70 & & & & \\
\hline & 8.grade (d) & 148 & 314,38 & & & & \\
\hline \multirow{4}{*}{ 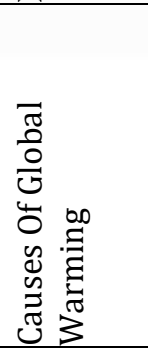 } & 5.grade(a) & 93 & 217,65 & \multirow{4}{*}{3} & \multirow{4}{*}{10,377} & \multirow{4}{*}{, $016^{*}$} & \multirow{4}{*}{$\begin{array}{l}a-b \\
a-c \\
a-d\end{array}$} \\
\hline & 6.grade(b) & 125 & 270,05 & & & & \\
\hline & 7.grade (c) & 158 & 268,21 & & & & \\
\hline & 8.grade (d) & 148 & 278,21 & & & & \\
\hline \multirow{4}{*}{ 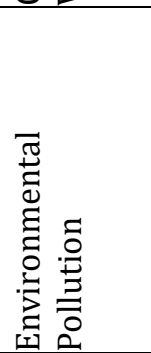 } & 5.grade (a) & 93 & 266,77 & \multirow{4}{*}{3} & \multirow{4}{*}{2,742} & \multirow{4}{*}{ 433 } & \multirow{4}{*}{ - } \\
\hline & 6.grade (b) & 125 & 244,77 & & & & \\
\hline & 7.grade (c) & 158 & 272,76 & & & & \\
\hline & 8.grade (d) & 148 & 263,84 & & & & \\
\hline 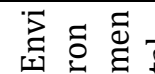 & 5.grade (a) & 93 & 246,67 & 3 & 3,471 & ,325 & - \\
\hline
\end{tabular}


Ablak, S., Yeșiltaș, E. (2020). Secondary School Students' Awareness of Environmental Education...

\begin{tabular}{|c|c|c|c|c|c|c|c|}
\hline & 6.grade (b) & 125 & 276,55 & & & & \\
\hline & 7.grade (c) & 158 & 271,18 & & & & \\
\hline & 8.grade $(d)$ & 148 & 251,32 & & & & \\
\hline \multirow{4}{*}{ 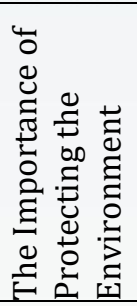 } & 5.grade (a) & 93 & 240,40 & \multirow{4}{*}{3} & \multirow{4}{*}{3,690} & \multirow{4}{*}{ 297 } & \multirow{4}{*}{-} \\
\hline & 6.grade (b) & 125 & 279,65 & & & & \\
\hline & 7.grade (c) & 158 & 262,72 & & & & \\
\hline & 8.grade $(d)$ & 148 & 261,67 & & & & \\
\hline \multirow{4}{*}{ 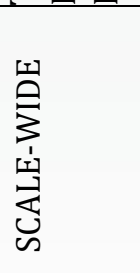 } & 5.grade (a) & 93 & 214,98 & \multirow{4}{*}{3} & \multirow{4}{*}{12,468} & \multirow{4}{*}{, $006^{*}$} & \multirow{4}{*}{$\begin{array}{l}a-b \\
a-c \\
a-d\end{array}$} \\
\hline & 6.grade (b) & 125 & 272,09 & & & & \\
\hline & 7.grade (c) & 158 & 263,42 & & & & \\
\hline & 8.grade (d) & 148 & 283,28 & & & & \\
\hline
\end{tabular}

$\left({ }^{*} \mathrm{p}<0,05\right)$

When Table 5 is examined, it is observed that a according to the grade variable $(p<, 05)$, the awareness levels of secondary schools students about the concepts of environmental education show significant difference in the lower dimensions of "human impact" and "causes of global warming". According to the results of the Mann-Whitney U test, which was conducted to examine between which groups the significant difference occurred, it was found to be in the human-effect subdimension of the difference between Grades 6 and 7 (MR=248,65). It is among all classes except class $(\mathrm{MR}=276,70)$; causes of global warming are in sub-dimension 5. 6 with class $(M R=248,65) .(M R=270,05), 7 .(M R=276,70)$ and $8 .(M R=278,21)$ is between classes; again 5 If across scale. 6 with class (MR=214,98). (MR=272,09), 7. $(M R=263,42)$ and 8 . $(M R=283,28)$ is observed to be between classes. 5 . when the sequence averages of the lower dimensions and the overall scale are examined, the significant difference is seen. It can be said that the levels of awareness about the concepts of environmental education relates to grade level, and the levels of awareness increase as the grade level increases.

Table 6 
Kruskal-Wallis test results on the levels of awareness levels about environmental education concepts by secondary school students according to the variable of maternal education

\begin{tabular}{|c|c|c|c|c|c|c|c|}
\hline Dimension & Grade & $\mathrm{N}$ & MR & Sd & $\chi^{2}$ & $\mathrm{p}$ & $\begin{array}{l}\text { Significant } \\
\text { Differences }\end{array}$ \\
\hline \multirow{5}{*}{ 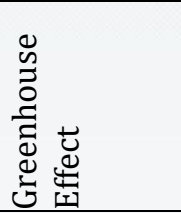 } & Secondary and & 84 & 279,43 & \multirow{5}{*}{3} & \multirow{5}{*}{3,138} & \multirow{5}{*}{ 371 } & \multirow{5}{*}{ - } \\
\hline & Primary School (a) & & & & & & \\
\hline & High School (b) & 126 & 257,10 & & & & \\
\hline & Graduate (c) & 208 & 268,28 & & & & \\
\hline & Postgraduate (d) & 106 & 244,17 & & & & \\
\hline \multirow{4}{*}{ 壱 } & $\begin{array}{l}\text { Secondary and } \\
\text { Primary School (a) }\end{array}$ & 84 & 240,86 & \multirow{4}{*}{3} & \multirow{4}{*}{5,340} & \multirow{4}{*}{,149 } & \multirow{4}{*}{-} \\
\hline & High School (b) & 126 & 248,42 & & & & \\
\hline & Graduate (c) & 208 & 268,91 & & & & \\
\hline & Postgraduate(d) & 106 & 283,80 & & & & \\
\hline \multirow{4}{*}{ 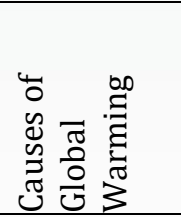 } & $\begin{array}{l}\text { Secondary and } \\
\text { Primary School (a) }\end{array}$ & 84 & 248,71 & \multirow{4}{*}{3} & \multirow{4}{*}{3,627} & \multirow{4}{*}{,305 } & \multirow{4}{*}{-} \\
\hline & High School (b) & 126 & 246,61 & & & & \\
\hline & Graduate (c) & 208 & 274,71 & & & & \\
\hline & Postgraduate (d) & 106 & 268,36 & & & & \\
\hline \multirow{4}{*}{ 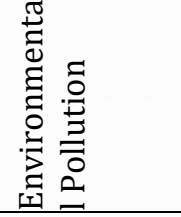 } & $\begin{array}{l}\text { Secondary and } \\
\text { Primary School (a) }\end{array}$ & 84 & 226,96 & \multirow{4}{*}{3} & \multirow{4}{*}{24,605} & \multirow{4}{*}{, $000^{*}$} & \multirow{4}{*}{$\begin{array}{l}a-c \\
a-d \\
b-c \\
b-d\end{array}$} \\
\hline & High School (b) & 126 & 223,19 & & & & \\
\hline & Graduate (c) & 208 & 293,16 & & & & \\
\hline & Postgraduate (d) & 106 & 277,22 & & & & \\
\hline \multirow{4}{*}{ 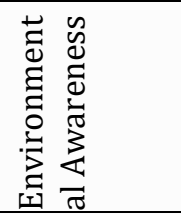 } & $\begin{array}{l}\text { Secondary and } \\
\text { Primary School (a) }\end{array}$ & 84 & 244,56 & \multirow{4}{*}{3} & \multirow{4}{*}{25,432} & \multirow{4}{*}{, $000^{*}$} & \multirow{4}{*}{$\begin{array}{l}a-b \\
a-c \\
b-c \\
b-d\end{array}$} \\
\hline & High School (b) & 126 & 210,81 & & & & \\
\hline & Graduate (c) & 208 & 291,15 & & & & \\
\hline & Postgraduate (d) & 106 & 281,95 & & & & \\
\hline \multirow{4}{*}{ 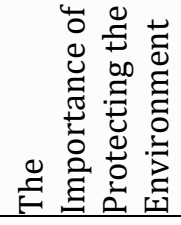 } & $\begin{array}{l}\text { Secondary and } \\
\text { Primary School (a) }\end{array}$ & 84 & 259,04 & \multirow{4}{*}{3} & \multirow{4}{*}{2,087} & \multirow{4}{*}{,555 } & \multirow{4}{*}{-} \\
\hline & High School (b) & 126 & 247,69 & & & & \\
\hline & Graduate (c) & 208 & 267,13 & & & & \\
\hline & Postgraduate (d) & 106 & 273,77 & & & & \\
\hline & Secondary and & 84 & 238,98 & & & & \\
\hline 됭 & Primary School (a) & & & & & & C \\
\hline 3 & High School (b) & 126 & 230,52 & 3 & 12,777 & $005^{*}$ & $b-c$ \\
\hline 孚 & Graduate (c) & 208 & 283,58 & & & & $b-d$ \\
\hline 胥 & Postgraduate (d) & 106 & 277,79 & & & & \\
\hline
\end{tabular}

$$
(* \mathrm{p}<0,05)
$$

When Table 6 is examined, it is observed that, according to the maternal education variable $(p<, 05)$, the levels of awareness levels about environmental education concepts by secondary school students shows a significant difference in the lower dimensions of "environmental pollution" and "environmental awareness". According to the Mann-Whitney $U$ test which is performed to examine significant differences amongst the groups, the difference in environmental pollution and subsize in the middle and the bottom (MR=248,71) high school with $(M R=223,19)$ all education levels, except between levels of education; environmental awareness subchild is between sizes size All; across the scale, it is seen that there are between secondary school and six $(M R=248.71)$ and high school (MR=248.71), high school 
and undergraduate $(M R=248.71)$ and graduate $(M R=248.71)$ levels of Education. When rank averages are examined across the scales, it can be said that secondary school students' awareness about the concepts of environmental education increases as levels of maternal education increases.

Table 7

Kruskal-Wallis Test Results on The Levels of Awareness Levels About Environmental Education Concepts by Secondary School Students According to The Variable of Paternal Education Status

\begin{tabular}{|c|c|c|c|c|c|c|c|}
\hline Dimension & Grade & $\mathrm{N}$ & MR & $\begin{array}{l}\mathrm{S} \\
\mathrm{d}\end{array}$ & $\chi^{2}$ & $\mathrm{p}$ & $\begin{array}{l}\text { Significant } \\
\text { Differences }\end{array}$ \\
\hline \multirow{4}{*}{ 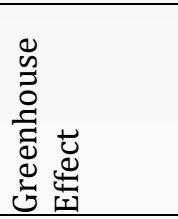 } & $\begin{array}{l}\text { Secondary and Primary } \\
\text { School (a) }\end{array}$ & 40 & 277,63 & \multirow{4}{*}{3} & \multirow{4}{*}{1,463} & \multirow{4}{*}{ 691 } & \multirow[t]{4}{*}{ 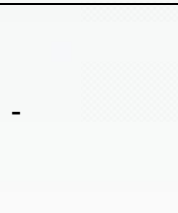 } \\
\hline & High School (b) & 126 & 249,80 & & & & \\
\hline & Graduate (c) & 232 & 264,37 & & & & \\
\hline & Postgraduate (d) & 126 & 266,95 & & & & \\
\hline \multirow{4}{*}{ 胥 } & $\begin{array}{l}\text { Secondary and Primary } \\
\text { School (a) }\end{array}$ & 40 & 221,61 & \multirow{4}{*}{3} & \multirow{4}{*}{10,474} & \multirow{4}{*}{, $015^{*}$} & \multirow{4}{*}{$\begin{array}{l}a-d \\
b-c \\
b-d\end{array}$} \\
\hline & High School (b) & 126 & 236,19 & & & & \\
\hline & Graduate (c) & 232 & 271,61 & & & & \\
\hline & Postgraduate (d) & 126 & 285,03 & & & & \\
\hline \multirow{4}{*}{ 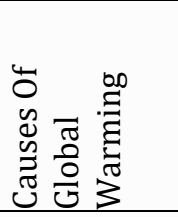 } & $\begin{array}{lll}\text { Secondary and } & \text { Primary } \\
\text { School (a) } & & \\
\end{array}$ & 40 & 218,18 & \multirow{4}{*}{3} & \multirow{4}{*}{8,886} & \multirow{4}{*}{,031* } & \multirow{4}{*}{$\begin{array}{l}a-c \\
b-c \\
b-d\end{array}$} \\
\hline & High School (b) & 126 & 240,32 & & & & \\
\hline & Graduate (c) & 232 & 277,43 & & & & \\
\hline & Postgraduate (d) & 126 & 271,26 & & & & \\
\hline \multirow{4}{*}{ 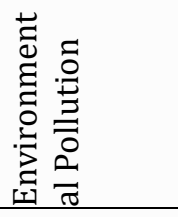 } & $\begin{array}{lll}\text { Secondary and Primary } \\
\text { School (a) }\end{array}$ & 40 & 203,76 & \multirow{4}{*}{3} & \multirow{4}{*}{21,886} & \multirow{4}{*}{, $000^{*}$} & \multirow{4}{*}{$\begin{array}{l}a-c \\
a-d \\
b-c\end{array}$} \\
\hline & High School (b) & 126 & 225,04 & & & & \\
\hline & Graduate (c) & 232 & 278,88 & & & & \\
\hline & Postgraduate (d) & 126 & 288,46 & & & & \\
\hline \multirow{4}{*}{ 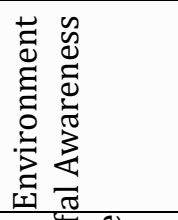 } & $\begin{array}{lll}\text { Secondary and Primary } \\
\text { School (a) }\end{array}$ & 40 & 199,76 & \multirow{4}{*}{3} & \multirow{4}{*}{17,427} & \multirow{4}{*}{, $001^{*}$} & \multirow{4}{*}{$\begin{array}{l}a-c \\
a-d \\
b-c \\
b-d\end{array}$} \\
\hline & High School (b) & 126 & 231,54 & & & & \\
\hline & Graduate (c) & 232 & 279,38 & & & & \\
\hline & Postgraduate (d) & 126 & 282,30 & & & & \\
\hline \multirow{4}{*}{ 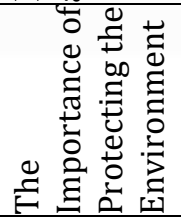 } & $\begin{array}{lll}\text { Secondary and Primary } \\
\text { School (a) }\end{array}$ & 40 & 249,68 & \multirow{4}{*}{3} & \multirow{4}{*}{1,658} & \multirow{4}{*}{,646 } & \multirow{4}{*}{-} \\
\hline & High School (b) & 126 & 256,29 & & & & \\
\hline & Graduate (c) & 232 & 271,74 & & & & \\
\hline & Postgraduate (d) & 126 & 255,77 & & & & \\
\hline \multirow{4}{*}{ 窅 } & $\begin{array}{l}\text { Secondary and Primary } \\
\text { School (a) }\end{array}$ & 40 & 204,59 & & & & $\mathrm{a}-\mathrm{c}$ \\
\hline & High School (b) & 126 & 228,05 & 3 & 17,873 &, $000^{*}$ & \\
\hline & Graduate (c) & 232 & 279,44 & & & & $\begin{array}{l}D-c \\
h-d\end{array}$ \\
\hline & Postgraduate (d) & 126 & 284,14 & & & & \\
\hline
\end{tabular}

$\left({ }^{*} \mathrm{p}<0,05\right)$

When Table 7 is examined, it is observed that, according to the paternal education variable $(\mathrm{p}<, 05)$, secondary school students' levels of awareness about the concepts of environmental education show a significant difference in all lower dimensions of the scale except the "greenhouse effect" and "importance of protecting the Environment" sub dimensions. The Mann-Whitney U test which is performed to 
examine significant differences among the groups shows the difference of human impact on sub-size in the middle and the bottom (MR=221,61) graduate $(M R=285,03)$, high school $(M R=236,19)$ with license $(M R=271,61)$ and graduate $(M R=285,03)$, the levels of education between; the causes of global warming for the junior high and kid's size six $(M R=218,18)$ graduate $(M R=271,26)$, high school $(M R=240,32)$ with license $(M R=277,43)$ and graduate $(M R=271,26)$, between levels of education; of environmental pollution, sub-middle and lower size (MR=203,76) with license $(M R=278,88)$ and graduate $(M R=288,46)$, high school $(M R=225,04)$ with license $(\mathrm{MR}=278,88)$ is in the level of Education; environmental awareness sub-dimension in the middle and the bottom $(M R=199,76)$ with license $(M R=279,38)$ and graduate $(M R=282,30)$, high school $(M R=231,54)$ with license $(M R=279,38)$ and graduate $(M R=282,30)$ in the level of education is; on the scale, the size of the secondary school and six $(M R=204.59)$ with undergraduate $(M R=279.44)$ and graduate $(M R=284.14)$, high school $(M R=228.05)$ with undergraduate $(M R=279.44)$ and graduate $(M R=284.14)$ levels of education are seen. When rank averages are examined across the scales, it can be said that secondary school students' awareness about the concepts of environmental education increases as the level of paternal education increases.

Table 8

Kruskal-Wallis Test Results on The Levels of Awareness Levels About Environmental Education Concepts by Secondary School Students According to Variable of Monthly Income Level of The Family

\begin{tabular}{|c|c|c|c|c|c|c|c|}
\hline Dimension & Grade & $\mathrm{N}$ & MR & $\mathrm{Sd}$ & $\chi^{2}$ & $\mathrm{P}$ & $\begin{array}{l}\text { Signf. } \\
\text { Differe } \\
\text { nces }\end{array}$ \\
\hline \multirow{3}{*}{$\begin{array}{l}\text { Greenhouse } \\
\text { Effect }\end{array}$} & $€ 3000$ less than (a) & 96 & 253,31 & \multirow{3}{*}{2} & \multirow{3}{*}{,877 } & \multirow{3}{*}{,645 } & \multirow{3}{*}{-} \\
\hline & € 3001-4000 (b) & 83 & 274,28 & & & & \\
\hline & € 4001 more than(c) & 45 & 262,22 & & & & \\
\hline \multirow[t]{3}{*}{ Human Effect } & $€ 3000$ less than (a) & 96 & 200,44 & \multirow{3}{*}{2} & \multirow{3}{*}{24,664} & \multirow{3}{*}{, $000^{*}$} & $a-b$ \\
\hline & € 3001-4000 (b) & 83 & 244,33 & & & & $a-c$ \\
\hline & € 4001 more than(c) & 345 & 284,14 & & & & $\mathrm{~b}-\mathrm{c}$ \\
\hline \multirow{3}{*}{$\begin{array}{l}\text { Causes of Global } \\
\text { Warming }\end{array}$} & $€ 3000$ less than (a) & 96 & 211,03 & \multirow{3}{*}{2} & \multirow{3}{*}{15,410} & \multirow{3}{*}{, $000^{*}$} & \multirow{3}{*}{$a-c$} \\
\hline & € 3001-4000 (b) & 83 & 254,62 & & & & \\
\hline & € 4001 more than(c) & 345 & 278,72 & & & & \\
\hline \multirow{3}{*}{$\begin{array}{l}\text { Environmental } \\
\text { Pollution }\end{array}$} & € 3000 less than (a) & 96 & 209,94 & \multirow{3}{*}{2} & \multirow{3}{*}{26,623} & \multirow{3}{*}{, $000^{*}$} & \multirow{3}{*}{$\begin{array}{l}a-c \\
b-c\end{array}$} \\
\hline & € 3001-4000 (b) & 83 & 226,29 & & & & \\
\hline & € 4001 more than (c) & 345 & 285,84 & & & & \\
\hline \multirow{3}{*}{$\begin{array}{l}\text { Environmental } \\
\text { Awareness }\end{array}$} & € 3000 less than (a) & 96 & 202,17 & \multirow{3}{*}{2} & \multirow{3}{*}{31,993} & \multirow{3}{*}{, $000^{*}$} & \multirow{3}{*}{$\begin{array}{l}a-c \\
b-c\end{array}$} \\
\hline & € 3001-4000 (b) & 83 & 222,51 & & & & \\
\hline & € 4001 more than (c) & 345 & 288,91 & & & & \\
\hline \multirow{3}{*}{$\begin{array}{l}\text { The Importance } \\
\text { of Protecting the } \\
\text { Environment }\end{array}$} & $€ 3000$ less than (a) & 96 & 250,09 & \multirow{3}{*}{2} & \multirow{3}{*}{5,343} & \multirow{3}{*}{,069 } & \multirow{3}{*}{-} \\
\hline & € 3001-4000 (b) & 83 & 233,96 & & & & \\
\hline & € 4001 more than(c) & 345 & 272,82 & & & & \\
\hline \multirow{3}{*}{ SCALE-WIDE } & $€ 3000$ less than (a) & 96 & 198,69 & \multirow{3}{*}{2} & \multirow{3}{*}{28,796} & \multirow{3}{*}{,000* } & \multirow{3}{*}{$\begin{array}{l}a-c \\
b-c\end{array}$} \\
\hline & € 3001-4000 (b) & 83 & 234,89 & & & & \\
\hline & $\begin{array}{l}\text { £ } 4001 \text { TL more than } \\
\text { (c) }\end{array}$ & 345 & 286,90 & & & & \\
\hline
\end{tabular}


When Table 8 is examined, it is observed that according to the monthly income level of the family $(\mathrm{p}<, 05)$ variable, awareness levels of secondary school students' about the concepts of environmental education show significant difference in all lower dimensions of the scale except the lower dimensions of "greenhouse effect" and "importance of protecting the environment". According to the results of the Mann-Whitney U test, which is conducted to examine which groups the difference is between, the difference is between all income levels in the lower human impact dimension.; the causes of global warming sub-in size only $€ 3000$ less than $(M R=211,03)$ with $€ 4001$ more than $(M R=278,72)$ is between the level of income; environmental pollution sub-in size of $€ 3000$ less than (MR=209,94) with $€ 4001$ more than $(M R=285,84), 3001-4000$ TL $(M R=226,29)$ with 4001 TL and above $(\mathrm{MR}=285,84)$ is between the level of income; environmental awareness subdimension $€ 3000$ less than $(M R=209,94)$ with $€ 4001$ more than $(M R=285,84)$, TL 3001-4000 ( $M R=226,29)$ with $€ 4001$ more than ( $M R=285,84)$ between income levels; in the overall scale, it is also seen that income levels $€ 3000$ and below $(M R=209.94)$ to TL 4001 and above (MR=285.84), TL 3001-4000 (MR=226.29) to $€$ 4001 more than $(\mathrm{MR}=285.84)$ are between. When rank averages are examined across the scales, it can be said that secondary school students' awareness of environmental education concepts increases as the the level of family's monthly income increases.

Table 9

The Results of The Mann-Whitney U Test on The Levels of Awareness Levels About Environmental Education Concepts by Secondary School Students According to The Variable of Speaking About Environmental Issues in The Family

\begin{tabular}{|c|c|c|c|c|c|c|}
\hline Situation & $\mathrm{N}$ & MR & Ordinal Sum & $\mathrm{U}$ & $\mathrm{Z}$ & $\mathrm{P}$ \\
\hline Yes & 373 & 277,46 & 103492,00 & \multirow[b]{2}{*}{$-22582,00$} & \multirow[b]{2}{*}{$-3,556$} & \multirow[b]{2}{*}{, $000^{*}$} \\
\hline No & 151 & 225,55 & 34058,00 & & & \\
\hline
\end{tabular}

$\left({ }^{*} \mathrm{p}<0,05\right)$

In Table 9, the Mann-Whitney $U$ test examined whether levels of awareness amongst secondary school students about the concepts of environmental education differed according to the variable of speaking about environmental issues of the family. As a result of the analysis, it is observed that secondary school students' awareness levels about environmental education concepts differ significantly compared to variable about the family's speech status on environmental issues $(\mathrm{U}=22582,00, \mathrm{p}>0.05)$. Based on this finding, the variable of conversation status about environmental issues in the family affects the levels of awareness demonstrated by secondary school students about the concepts of environmental education.

\section{Conclusion, Discussion and Suggestions}

In this study, it is concluded that levels of awareness about concepts of environmental education demonstrated by secondary school students is high in terms of their general level of awareness. Çelik (2020) conducted a study on students at grade level and also found that students have high environmental 
awareness in general. Similarly, the study titled Determining Primary School Students Environmental Awareness conducted by Çelikler, Aksan \& Yenikalaycı (2019) concluded that primary school students' levels of environmental awareness is high. These results support the results reached from the current research.

It is concluded that the gender variable does not make any significant difference in secondary school students' levels of awareness about environmental education concepts. Similar results have been achieved in research conducted by Ötün, Artun, Bakırcl, Tozlu \& Durukan (2017) and also Erdem, Meriç, Meriç (2019) and Çelik (2020). On the other hand, a similar result was reached in the study conducted by Mert (2006) at the point of environmental sensitivity, which can be evaluated in a similar category with awareness although not directly on awareness about environmental education concepts. In this sense, it was determined that there was no difference between male and female students in terms of them being environmentally sensitive. Such a result can be attributed to the nature of the environmental education received by the students who make up the current study group.

It is concluded that the levels of awareness levels by secondary school students about the concepts of environmental education showed significant difference in the lower dimensions of "human impact" and "causes of global warming" according to the grade-level variable. When the sequence averages of the lower dimensions and the overall scale are examined, a significant difference is seen; the grades which had the lowest level of awareness about the concepts of environmental education concepts were the lower grades and the level of awareness increased as the grade level increased. There is no doubt this situation occurs in secondary school programs for both Social Studies, Science and elective environmental education courses across Grade 6, Grade 7 and Grade 8. It is effective to have more intensive content on environmental and environmental education issues at each grade level. A similar result to this was also obtained in the study by Gök (2012) about environmental knowledge among secondary school students in Grade 8. It was concluded that grades were higher.

It is concluded that the awareness levels of secondary school students about the concepts of environmental education showed a significant difference in the lower dimensions of "environmental pollution" and "environmental awareness" according to the maternal education variable. When rank averages are examined across the scales, it can be said that secondary school students' levels of awareness about environmental education concepts increases as levels of maternal education increase. Based on this result, it is possible to say that the increase in maternal education levels affects the child's awareness of the environmental education concepts. In the study titled Examining different kinds of variables affecting secondary school students' awareness about environmental education concepts conducted by Ötün, Artun, Bakırcl, Tozlu \& Durukan (2017), a significant difference was reached with respect to the levels of maternal education. According to the paternal education variable it is concluded that the awareness levels of secondary school students about environmental education concepts showed significant difference in all the lower dimensions of the scale except the lower dimensions of "greenhouse effect" and "importance of protecting the environment". When rank 
averages are examined across the scales, it can be said that secondary school students ' awareness levels about the concepts of environmental education increases as the levels of paternal education increases. A similar result was obtained in the study by Erdem, Meriç, \& Meriç (2019). According to the results obtained by authors from the study Evaluation of environmental awareness of Primary School students in terms of various variables, it was found that levels of environmental awareness by students whose father was a university graduate were higher than those whose father was a secondary school graduate. From this conclusion, it is possible to say that increases in the level of paternal education affects the child's awareness of environmental education concepts.

According to the monthly income level of the family, it is concluded that the levels of awareness by secondary school students about environmental education concepts showed significant difference in all lower dimensions of the scale except the "greenhouse effect" and "importance of protecting the Environment" sub dimensions. When rank averages are examined across the scales, it can be said that secondary school students' level of awareness about the concepts of environmental education increases as the level of family's monthly income increases. From this point on, it can be said that socio-economic development affects the perspective of and awareness about the concepts of environmental education. A similar result was shown by Uzun and Sağlam (2005) in their study about socio-economic status and levels of environmental awareness and environmental academic achievement; it was observed that the difference between the environmental awareness averages of students with high and low socio-economic levels was in favor of students with high socio-economic levels. However, the study conducted by Irmak-Kazazoğlu (2020) showed that students' levels of environmental awareness did not differ significantly according to income level. The variable of speaking about environmental issues in the family does affect secondary school students' levels of awareness about environmental education. From here on, the conversations in the family about environmental problems and concepts related to the environment (environmental education, environmental problems, concepts of environmental education, etc.) do affect the children and can be said to increase their levels of awareness. An assessment of this variable has not been reached in the literature.

Based on these results, it is proposed to increase the content and gains about the concepts of environmental education in secondary school education programs. Such a suggestion is made in order to help increase the levels of awareness by secondary school students about the concepts of environmental education, especially about the environment and environmental problems. As a result of the increase in parental education levels also contributing to an increase in the level of student awareness, it is recommended to plan educational activities within the framework of environmental education for parents with low education levels. The result of domestic conversations from parents about environmental issues has been shown to increase the levels of awareness about environmental education demonstrated by students, therefore, it is also suggested to organize seminars and trainings with an environmental theme, especially environmental education, environmental problems, environmental education concepts, The current study aimed to determine the levels of awareness about environmental education concepts 
amongst middle school students. Studies for different levels of education can be carried out in different studies. This research was conducted in a scan pattern from quantitative research methods. In order to be informed in depth, it is recommended to work with qualitative research designs.

\section{References}

Ablak, S. (2013). Ortaokul öğrencilerinin çevreye yönelik duyuşsal eğilimleri. In Demirci, A. \& Arı, Y. (Ed). Coğrafyacılar Derneği Yıllık Kongresi Bildiriler Kitabı (s.632-638). İstanbul: Fatih Üniversitesi

Akınoğlu, 0., \& Sarı, A. (2009). Environmental education in primary school curriculum. Marmara University Atatürk Faculty of Education Journal of Educational Sciences, 30, 5-29. Retrieved from https://dergipark.org.tr/tr/pub/maruaebd

Aksoy, B., \& Karatekin, K. (2011). Affective tendencies of undergraduate students in different programs toward the environment. The Journal of Turkish Social Research, 153 (153),23-36. Retrieved from https://dergipark.org.tr/tr/pub /tsadergisi/issue/21488/230332

Altunoğlu, B., \& Atav, E. (2009). Secondary school students' environmental risk perception. Hacettepe University Journal of Education, 36(36),1-11.Retrieved from https://dergipark.org.tr/tr/pub/hunefd/issue/7800/10219/

Arslan, H. (2011). As a "Direct Action Movement" Greenpeace. SDU Faculty of Arts and Science Journal of Social Sciences, 23, 247-258.

Artvinli, E., \& Demir, Z.M. (2018). Türkiye ve Çekya sınıf öğretmenliği lisans programlarında çevre eğitimi. In Ulusuy, K. \& Yazıcı, K. (Ed.) 2. Uluslararası Eğitim ve Değerler Sempozyumu Bildiri Tam Metinleri Sempozyum E-Kitabı içnde (s.324-333). Lara/Antalya.

Artvinli, E., Aydın, R., \& Terzi, İ. (2019). Environmental attitude levels of primary teachers candidates. Osmangazi Journal of Educational Research, 6(2), 62-78. Retrieved from https://ojer.ogu.edu.tr/Storage/OsmangaziJournalOfEducationalResearch/Uploads /OJER-V6-N2-1(1).pdf

Aydın, F., \& Ünaldı, Ü.E. (2013). Geography teacher candidates' attitudes towards sustainable environment, Kalem International Journal of Education and Human Sciences, 3 (1), 11-42.

Atalay, İ. (2012). Genel Fiziki Coğrafya. İzmir: META.

Atasoy, E. (2005). Environmental education: A study for elementary school students' environmental attitude and knowledge. (Unpublished doctoral thesis.) Uludag University Institute of Social Sciences, Bursa. Retrieved from: https://tez.yok.gov.tr

Atasoy, E. \& Ertürk, H. (2008). A field study about environmental knowledge and attitudes of elementary school students. Erzincan University Journal of Education Faculty,10 (1), 105-122.

Bozdemir, H. ve Faiz, M. (2018). Ecocentric, Antropocentric and Antipathetic Attitudes of Teacher Candidates towards the Environment. Sakarya University Journal of Education, 8(1), 61-75. https://doi.org/10.19126/suje.330546

Bozkurt, O., \& Cansüngü, Ö. (2002). Primary school students' misconceptions about greenhouse effect in environment education. Hacettepe University Journal of Education, 23, 67-73. 
Büyüköztürk, Ş., Kılıç Çakmak, E., Akgün, Ö., Karadeniz, Ş., \& Demirel, F. (2014). Bilimsel Araştırma Yöntemleri (17. baskı). Ankara: Pegem.

Callenbach, E. (2012). Ekoloji cep rehberi (E. Özkan, Çev.). Ankara: Sinek Sekiz.

Chauhan, B. (2008). Environmental studies. New Delhi: University Science Press.

Creswell, J. W. (2013). Research design (S. B. Demir, Çev. Ed.). Ankara: Eğiten Kitap.

Çabuk, B. \& Karacaoğlu, C. (2003). Examining the environmental sensitivity of university students. Ankara University Journal of Faculty of Educational Sciences, 36(1-2), 189198.

Çelik, A. (2020). Investigation of environmental awareness and cognitive structures of the 5th grade students. International Journal of Geography and Geography Education (IGGE), 41, 73-87. https://doi.org/10.32003/igge.638890

Çelikler, D., Aksan, Z., \& Yenikalaycı, N. (2019). The determination on the elementary school students' awareness related to the environment. Inonu University Journal of the Faculty of Education, 20(2), 425-438. https://doi.org/10.17679/inuefd.450030

Çepel, N. (1992). Doğa, çevre, ekoloji ve insanlığın ekolojik sorunları. İstanbul: Altın.

Çepel, N. (2006). Ekoloji, doğal yaşam dünyaları ve insan. Ankara: Palme Yayıncılık.

Çevre ve Orman Bakanlığı (2004). Türkiye çevre atlası. Ankara: Çevre Envanteri Dairesi Başkanlığl.

Çetin, G. \& Nişancı, S. H. (2010). Enhancing students' environmental awareness. Procedia Social and Behavioral Sciences, 2, 1830-1834.

Değirmenci, M. (2013). Examination of elementary students' attitudes towards the environment in terms of different variables (Example of the province of Kayseri). Middle Eastern \& African Journal of Educational Research, 3, 59-68.

Demir, E. \& Yalçın, H. (2014). Environmental education in Turkey. Turkish Journal of Scientific Reviews, 7 (2), 07-18.

Demirbaş, M \& Pektaş, H. (2009). Elementary students' levels of realization of basic concepts related with environment problem. Necatibey Faculty of Education Electronic Journal of Science and Mathematics Education, 3(2), 195-211. Retrieved from https://dergipark.org.tr/tr/download/article-file/39788

Denhez, F. (2007). Küresel ısınma atlası (2 baskı). (Ö. Adadağ, Çeviri Ed.) İstanbul: NTV.

Dev-Karakoçan, E. \& Kurtdede-Fidan, N. (2020). Awareness on environmental education of classroom teachers. Mediterranean Journal of Educational Research, 14 (31), 422-444

Doherty, G., Claybourne, A., \& Davidson, S. (2011). Coğrafya Ansiklopedisi ve Dünya Atlası (M. Zor, Çeviri Ed.) Ankara: TÜBİTAK Popüler Bilim Kitapları 354.

Erdem, M., Meriç, E. \& Meriç, A. (2019). Evaluation of environmental awareness of primary school students in terms of various variables. Journal of STEAM Education, 2(1), 2138.

Erdoğan, N. (2003). Çevre ve ekoturizm (1 baskı). İstanbul: Erk.

Erkan, S., Şafak, Ş. \& Yertutan, C. (2011). The role of family in creating awareness of sustainable development and environment. Sosyoekonomi, 2011(1), 145-158.

Erol, G. (2005). Primary school teaching department sophomore students' attitudes toward environment and environmental problems. (Unpublished master's thesis). Pamukkale 
University Institute of Science, Denizli. Retrieved from: https://tez.yok.gov.tr.

Erol, G. H. \& Gezer, K. (2006). Prospective of elementary school teacher's attitudes towards environment and environmental problems. International Journal of Environmental and Science Education, 1 (1), 65-77.

Erten, S. (2003). By the study of a teaching model on development of awareness on "garbage reduction" for the fifth-class students, Hacettepe University Journal of Education, 25 (25), 94-103.

Erten, S. (2004). What is environmental education and environmental awareness, how should environmental education be? Journal of Environment and Human, 65 (66), 113.

Ertürk, H. (1994). Çevre Bilimlerine Giriş. Bursa: Uludağ Üniversitesi Güçlendirme Vakfı.

Gök, E. (2012). A survey on elementary school students? environmental knowledge and environmental attitudes (unpublished master's thesis). Necmettin Erbakan University Institute of Educational Sciences, Konya. Retrieved from: https://tez.yok.gov.tr.

Gökçe, N., Kaya, E., Aktay, S. \& Özden, M. (2007). Elementary students' attitudes towards environment. Elementary Education Online, 6(3), 452-468.

Güney, E. (2004). Çevre Sorunları Coğrafyası. Ankara: Gündüz.

Ilgar, R. (2007). The role and importance of extended education in environmental education. Ondokuz Mayıs University Journal of Education Faculty, 23, 38-50.

Irmak-Kazazoğlu, T. (2020). Investigation of environmental awareness levels of university students and their behaviors towards environmental problems (Unpublished master's thesis). Hacettepe University Institute of Social Sciences, Ankara. Retrieved from: https://tez.yok.gov.tr.

Karataş, A., \& Aslan, G. (2012). The role of environmental education in gaining environmental awareness for elementary school students: the sample of ecologybased summer camp project. Zeitschrift für die Welt der Türken Journal of World of Turks, 4 (2), 259-276.

Karatekin, K. (2011). The determination of environmental literacy levels of pre-service teachers of social studies, (unpublished doctoral thesis). Gazi University, Institute of Educational Sciences, Ankara. Retrieved from: https://tez.yok.gov.tr

Kaya, N., Çobanoğlu, M.T., \& Artvinli, E. (2010). Environmental education studies in the world and Turkey for sustainable development. TÜCAUM VI. Coğrafya Sempozyumu Bildiriler Kitabı, Ankara, 407-418.

Kışlalıoğlu, M., \& Berkes, F. (2001). Ekoloji ve Çevre Bilimleri (3. baskı). İstanbul: Remzi.

MEB. (2015). Ortaokul Çevre Eğitimi Dersi Öğretim Programı. Ankara

MEB. (2018). Sosyal Bilgiler Dersi Öğretim Programı (illkokul ve Ortaokul 4, 5, 6 ve 7. Sinıflar). Ankara.

Mert, M. (2006). Determination of consciousness level of high school students on the environmental training and solid wastes topics, (unpublished master thesis), Hacettepe University, Institute of Science and Technology, Ankara. Retrieved from: https://tez.yok.gov.tr

Meydan, A. \& Doğu, S. (2008). Evaluation of the views of the second-grade primary school students on environmental problems according to some. Journal of Selcuk University Ahmet Kelesoglu Education Faculty, 26, 267-277. 
Önder, R. (2015). Primary school students' attitudes towards environment. Karabük University Journal of Institute of Social Sciences, 5 (1), 115-124.

Ötün, Y., Artun, H., Temur, A. \& Tozlu, İ. (2017). Environmental education concepts awareness scale for secondary school students: a validity and reliability study. Journal of Yüzüncü Yıl University Faculty of Education, 14 (1), 511-528. Retrieved from http://dx.doi.org/10.23891/efdyyu.2017.20

Ötün, Y., Artun, H., Bakırcı, H., Tozlu, İ., \& Durukan, A. (2017). Ortaokul öğrencilerinin çevre eğitimi kavramlarına yönelik farkındalıklarına etki eden farklı türden değişkenlerin incelenmesi. In Ejer 2017 Bildiri Özetleri Kitabı (s. 660-662). Denizli: Pamukkale Üniversitesi. Retrieved from: https://ejercongress.org/pdf/bildiriozetleri2017+.pdf

Özey, R. (2001). Çevre sorunları. İstanbul: Aktif.

Özgen, N., (2012). Teacher candidates' attitudes towards environmental problems: the example of Turkey. Kastamonu Education Journal, 20 (2), 403-422.

Özmen, D., Çetinkaya, Ç. A. ve Nehir, S. (2005). University students' attitudes towards environmental problems. TAF Preventive Medicine Bulletin, 4 (6), 330-344.

Öztürk, T. \& Zaimoğlu Öztürk, F. (2015). Opinions of pre-service teachers about environment and environmental education (Ordu University sample). Ballkesir University the Journal of Social Sciences Institute, 18 (33), 115-132.

Solmaz, G. (2010). The effects of instruction based on conceptual understanding through cooperative learning on the students understanding of environmental concepts and environmental awareness: The sample of 7th grade unit of human and environment, (Unpublished master thesis). Dokuz Eylul University Institute of Educational Sciences, İzmir.

Sungur, S. A. (2017). Ethical attitudes of undergraduates towards environment. The Journal of Academic Social Science, 41, 469-479.

Şama, E. (2003). Teacher candidates' attitudes toward environmental problems. Gazi University Journal of Gazi Educational Faculty, 23 (2), 99-110.

Türk Dil Kurumu. (2019). Türk Dil Kurumu: Retrieved from https://sozluk.gov.tr/ .

Uzun, N., \& Sağlam, N. (2005). Effect of socio-economic status on environmental awareness and environmental academic success. Hacettepe University Journal of Education, 29 (29), 194-202. Retrieved from: https://dergipark.org.tr/tr/pub/hunefd /issue/7809/102463

Ünal, F. (2011). The place of sustainable environmental education in primary education. Journal of Education in the Light of Science and Mind, 132, 68-73.

Yangın, S. \& Filik İşçen, C. (2013). Environmental education: current situation and problems faced (examples of Recep Tayyip Erdogan University and Eskisehir Osmangazi University). Electronic Journal of Social Sciences, 12(46), 131-150.

Yılmaz, A., Morgil, İ., Aktuğ, P. \& Göbekli, İ. (2002). Knowledge of the secondary school and university students on the environment, environmental concepts and problems and suggestions. Hacettepe University Journal of Education, 72, 156-162.

Yılmaz, N. (2019). A multidimensional study of science, social studies, and Turkish teacher candidates' behavior and attitudes about environmental problems and environment, (Unpublished master thesis). Gaziantep University Institute of Educational Sciences, Gaziantep. 
Yücel, S.A. \& Morgil, F. İ. (1998) Researching the environmental phenomenon in higher education, Hacettepe University Journal of Education, 14, 84-91.

\section{Biographical Statements}

Selman ABLAK is currently an assistant professor in the Department of Social Studies Education, Faculty of Education, Sivas Cumhuriyet University. He has national and international studies on social studies education and skills education.

Erkan YEŞILTAŞ is an associate professor in the Department of Social Studies Education, Department of Turkish and Social Sciences Education, Faculty of Education, Sivas Cumhuriyet University. He has national and international studies on social studies education and computer-based Social Studies teaching. 